\title{
Dampak Kebijakan Pajak Pertambahan Nilai Terhadap Kinerja Ekonomi Kopi di Indonesia
}

\section{The Effect of Value Added Tax to Coffee Economical Performance in Indonesia}

\author{
Favian Arsyi Suhardoyo $^{1 *}$, Syafrial ${ }^{2}$, Abdul Wahib Muhaimin ${ }^{2}$ \\ ${ }^{1}$ Pascasarjana Program Studi Ekonomi Pertanian, Fakultas Pertanian, Universitas Brawijaya \\ ${ }^{2}$ Jurusan Sosial Ekonomi, Fakultas Pertanian, Universitas Brawijaya, Jl. Veteran Malang 65145, Jawa \\ Timur, Indonesia
}

Diterima: 24 Agustus 2016; Direvisi: 15 Oktober 2016; Disetujui: 5 Desember 2016

\begin{abstract}
ABSTRAK
Di Indonesia, kopi merupakan salah satu komoditi perkebunan yang memiliki nilai dan volume ekspor yang besar, sehingga pemerintah memberlakukan pajak pertambahan nilai bagi eksportir kopi sebesar $10 \%$ dengan tujuan untuk stabilisasi harga kopi pasar domestik. Pemberlakuan regulasi ini berdampak negatif bagi bara pelaku usaha kopi yaitu penambahan biaya input sehingga produksi kopi terus mengalami penurunan. Penelitian ini bertujuan untuk menganalisis faktor - faktor yang mempengaruhi kinerja ekonomi kopi di Indonesia, dampak kebijakan pajak pertambahan nilai terhadap kinerja ekonomi kopi di Indonesia, serta alternatif kebijaka yang sesuai dalam peningkatan kinerja ekonomi kopi di Indonesia. Metode yang digunakan adalah two-stage-least-square (2SLS). Hasil penelitian menunjukkan bahwa permintaan kopi domestik merupakan faktor yang berpengaruh terhadap kinerja ekonomi kopi di Indonesia, dan dampak penerapan kebijakan pajak pertambahan nilai akan mengurangi kinerja ekonomi kopi di Indonesia, serta alternatif kebijakan yang sesuai adalah penghapusan kebijakan pajak pertambahan nilai di Indonesia.
\end{abstract}

Kata kunci: kopi; pajak pertambahan nilai; kinerja ekonomi kopi; two-stage-least-square

\begin{abstract}
Indonesian coffee is one of the plantation commodity that has a large volume and value of export, so that the government impose a value-added tax for exporters of coffee by $10 \%$ in order to stabilize the domestic and international markets. Enforcement of these regulations negatively impacting coffee businesses embers. Input costs increased and also coffee production decreased. This study aimed to analyze the factors that affect the economical performance of coffee in Indonesia, value-added tax policy impact on economical performance of coffee in Indonesia, as well as the appropriate policy alternatives in improving the economical performance of coffee in Indonesia. The method is two-stage-least-squares (2SLS). The results showed that the domestic demand for coffee is the most affecting factor of the coffee economical performance in Indonesia, and the impact of the value-added tax policy would reduce the economical performance of coffee in Indonesia, as well as an appropriate alternative policy is the elimination of value-added tax policy in Indonesia.
\end{abstract}

Keywords: coffee; value-added tax; coffee economic performance; two-stage-least-squares

\section{Pendahuluan}

Dalam upaya peningkatan kinerja ekonomi komoditi unggulan, sektor pertanian menjadi satu hal yang diharuskan menjadi perhatian utama oleh pemerintah. Menurut Anindita (2008),

\footnotetext{
${ }^{*}$ Penulis Korespondensi.

E-mail: favian.arsyi.suhardoyo@ gmail.com HP: +62-8127338950, Fax: +62-711-82933
}

sektor pertanian menjadi penting dikarenakan sektor pertanian merupakan sektor yang mengandalkan kemampuan sumber daya alam. Sehingga penggunaan input dari impor relatif lebih rendah dari sektor lain, terutama sektor industri.

Salah satu negara yang memiliki upaya nyata dalam peningkatan devisa negara dengan peningkatan kinerja ekonomi komoditi pertanian adalah Indonesia. Berdasarkan data yang 
diperoleh BPS (2014), neraca perdagangan sektor pertanian masih berada dalam kondisi surplus. Menurut Kementrian Pertanian (2013) surplus neraca perdagangan dari sisi volume tahun 2008 2012 mengalami peningkatan dengan rata-rata sebesar $1,14 \%$ per tahun. Demikian pula jika dilihat dari sisi nilai neraca perdagangan menunjukkan peningkatan surplus dengan ratarata sebesar 5,96\% per tahun.

Menurut Pusat Data dan Sistem Informasi Kementerian Pertanian (2015), terdapat 5 komoditi pertanian yang memiliki nilai ekspor lebih dari US\$ 1.000.000.000 atau menjadi komoditi unggulan. Salah satunya adalah kopi. Kopi memiliki nilai ekspor sebesar US\$ 1.039.609.000. Hal ini disebabkan karena kopi memiliki perbandingan yang besar antara produksi dan konsumsi. Rata - rata produksi kopi dalam negeri dari tahun 2011 - 2014 adalah 600.000 ton dengan tingkat konsumsi rata - rata 200.000 ton (International Coffee Organization, 2015).

Dalam hal menjalankan perdagangan global, pelaku utama perdagangan membutuhkan regulasi - regulasi dari pemerintah. Dalam hal melakukan ekspor kopi, eksportir kopi di Indonesia diberlakukan Pajak Pertambahan Nilai sebesar $10 \%$ yang mulai berlaku pada tanggal 25 Juli 2014 berdasarkan Surat Edaran Dirjen Pajak Nomor SE-24/-PJ/2014 dan regulasi ini sudah diatur dalan Undang - undang Nomor 7 tahun 1994 tentang Pajak Pertambahan Nilai.

Pemberlakuan pajak pertambahan nilai $10 \%$ akan berdampak pada penambahan modal bagi eksportir kopi. Selain penambahan modal bagi eksportir, produsen kopi juga merasakan dampak dari pemberlakuan PPN ini dalam skala mikro ataupun makro. Eriyanto (2015) menambahkan bahwa eksportir akan menurunkan harga kopi yang dibeli di tingkat petani akibat menambah biaya ekspor. Sehingga, terjadi penurunan luas lahan perkebunan kopi baik dari sisi perkebunan rakyat maupun besar.

Beberapa penelitian mengenai komoditi kopi dan kinerja ekonominya telah dilakukan sebelumnya. Penelitian yang dilakukan oleh Hakim (2008) mengenai dampak liberalisasi perdagangan dunia terhadap permintaan dan penawaran kopi di Indonesia. Hasil penelitian menunjukkan bahwa penawaran kopi di Indonesia dibentuk oleh beberapa faktor, diantaranya adalah produksi kopi Indonesia ditambah jumlah stok kopi di Indonesia ditambah impor kopi di Indonesia dikurangi ekspor kopi di Indonesia. Sedangkan permintaan kopi di
Indonesia dipengaruhi oleh harga kopi arabika di Indonesia, jumlah impor kopi Indonesia, jumlah penduduk Indonesia, dan harga gula di Indonesia. Sedangkan penelitian yang dilakukan oleh Zuhdi (2014), mengenai faktor - faktor yang berpengaruh terhadap pangsa pasar ekspor kopi Indonesia di pasar internasional. Hasil penelitian ini menunjukkan bahwa luas area perkebunan kopi Indonesia dan harga kopi dunia tidak berpengaruh signifikan terhadap pangsa ekspor kopi Indonesia, sedangkan produktivitas kopi Indonesia, pangsa ekspor kopi Brazil dan Vietnam berpengaruh signifikan terhadap pangsa ekspor kopi Indonesia.

Dari beberapa penelitian di atas maka didapatkan kinerja ekonomi kopi yang terkait dalam penelitian ini adalah (1) Penawaran Kopi Domestik, (2) Total Produksi Kopi Indonesia, (3) Produktivitas Kopi Indonesia, (4) Luas areal panen kopi di Indonesia, (5) Permintaan Kopi Indonesia, (6) Harga Kopi Indonesia, (7) Permintaan Kopi Dunia, (8) Ekspor Kopi Indonesia, (9) Ekspor Kopi Kolombia, (10) Ekspor Kopi Brazil (11) Impor Kopi Amerika Serikat, dan (12) Impor Kopi Jepang.

Dengan peningkatan beberapa indikator kinerja ekonomi kopi, maka diharapkan peningkatan devisa negara melalu ekspor komoditi unggulan melalu komoditi kopi. Hal ini dikarenakan komoditi kopi memiliki potensi pasar internasional yang luas dengan sumber daya alam yang mendukung. Kecendereungan negara - negara besar seperti Amerika Serikat dan Jepang dalam mengkonsumsi pasar merupakan salah satu contoh konkrit dari potensi pasar kopi Indonesia.

Berdasarkan pemaparan di atas maka penting dilakukan penelitian mengenai dampak pemberlakuan kebijakan pajak pertambahan nilai pada komoditi kopi terhadap kinerja ekonomi kopi di Indonesia dalam upaya memaparkan kelayakan kebijakan pajak pertambahan nilai terhadap komoditi kopi di Indonesia.

Penelitian ini bertujuan untuk 1) Menganalisis faktor - faktor yang mempengaruhi kinerja ekonomi kopi di Indonesia, 2) Menganalisis dampak kebijakan pembayaran pajak pertambahan nilai $10 \%$ terhadap kinerja ekonomi kopi di Indonesia, dan 3) Menganalisis alternatif kebijakan yang sesuai dalam peningkatan kinerja ekonomi kopi di Indonesia. 


\section{Metode Penelitian}

\subsection{Metode Pengumpulan Data}

Data yang dipergunakan dalam penelitian ini adalah data tahunan yang (time series) yang memiliki rentang waktu antara tahun 1995 2015. Pada penelitian ini data yang digunakan adalah data sekunder dan diperoleh melalui dokumentasi dari berbagai sumber yang mendukung penelitian, diantaranya data berasal dari situs resmi Badan Pusat Statistik, situs resmi Kementrian Pertanian, situs resmi Kementrian Perindustrian, situs resmi Food and Agriculture Organization of The United Nations (FAOSTAT), situs resmi International Trade Center (ITC), dan situs resmi World Bank.

\subsection{Metode Analisis Data}

Analisis data yang dilakukan dalam penelitian ini diselaraskan dengan tujuan dari penelitian ini. Oleh karena itu yang dilakukan dalam penelitian ini menggunakan metode twostage-least-square (2SLS) dan melakukan analisis dampak kebijakan PPN 10\% dengan beberapa kemungkinan presentase PPN menggunakan simulation non linier (SIMLIN). Berikut merupakan uraian rinci mengenai metode analisis data yang digunakan.

\section{a. Analisis Faktor - faktor yang Mempengaruhi Kinerja Ekonomi Kopi Indonesia}

Dalam menganalisis faktor - faktor yang mempengaruhi ekspor kopi di Indonesia, maka dilakukan analisis model simultan dengan spesifikasi model sebagai berikut yang disusun sesuai dengan teori yang terkait dan penelitian terdahulu.
a) SKINA $=$ PRODK - XKINA
b) PRODK =LAPK $x$ PRDKVK
c) PRDKVK $=\mathrm{a}_{0}+\mathrm{a}_{1} \mathrm{LAPK}+\mathrm{a}_{2} \mathrm{HPPK}+$ $\mathrm{a}_{3} \mathrm{PRDKVK}_{\mathrm{t}-1}+\mathrm{a}_{4} \mathrm{PKD}+\mathrm{a}_{5} \mathrm{~W}+$
$\mathrm{a}_{6} \mathrm{PPN}+\varepsilon \ldots \ldots \ldots \ldots \ldots \ldots \ldots \ldots \ldots . .(3)$
d) LAPK $=b_{0}+b_{1}$ PKD $+b_{2}$ PTD $+b_{3}$ LAPK $_{t-1}+$

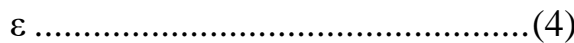
e) $\mathrm{DKD}=\mathrm{c}_{0}+\mathrm{c}_{1} \mathrm{PKD}+\mathrm{c}_{2} \mathrm{POP}+\mathrm{c}_{3} \mathrm{I}+\mathrm{c}_{4} \mathrm{PTD}+$
f) $P K D=d_{0}+d_{1} P K W+d_{2} E R+d_{3} P_{\text {KND }}+$ $\mathrm{d}_{4}$ SKINA $+\varepsilon \ldots \ldots \ldots \ldots \ldots \ldots \ldots \ldots \ldots \ldots \ldots . . .(6)$
g) $\mathrm{DKW}=\mathrm{e}_{0}+\mathrm{e}_{1} \mathrm{PKW}+\mathrm{e}_{2}$ XKINA $+\mathrm{e}_{3}$ XKBRA $+\mathrm{e}_{4} \mathrm{XKCOL}+\varepsilon$
h) XKINA $=f_{0}+f_{1} P K W+f_{2}$ ER $+f_{3}$ PRODK + $\mathrm{f}_{4} \mathrm{DKW}+\mathrm{f}_{5}$ XKBRA $+\mathrm{f}_{6}$ XKCOL + $\mathrm{f}_{7} \mathrm{PPN}+\varepsilon$

i) XKBRA $=\mathrm{h}_{0}+\mathrm{h}_{1} \mathrm{PKW}+\mathrm{h}_{3}$ ERBRA + $\mathrm{h}_{4}$ PRODKBRA $+\mathrm{h}_{5}$ DKW $+\mathrm{h}_{6} \mathrm{XKBRA}_{\mathrm{t}-1}+\varepsilon \ldots \ldots \ldots \ldots \ldots \ldots . . .(10)$

j) MKUSA $=\mathrm{i}_{0}+\mathrm{i}_{1} \mathrm{PKW}+\mathrm{i}_{2}$ KKUSA + $\mathrm{i}_{3}$ MKUSA $_{\mathrm{t}-1}+\varepsilon \ldots \ldots \ldots \ldots \ldots \ldots \ldots . . .(11)$

k) MKJEP $=\mathrm{j}_{0}+\mathrm{j}_{1}$ PKW $+\mathrm{j}_{2}$ ERJEP $+\mathrm{j}_{3}$ KKJEP $+\mathrm{j}_{4} \mathrm{MKJEP}_{\mathrm{t}-1}+\varepsilon$

Dimana :

Variabel Endogen :

SKINA $=$ Penawaran Kopi Domestik

PRODK = Total Produksi Kopi Indonesia

PRDKVK = Produktivitas Kopi Indonesia

LAPK = Luas areal panen kopi di Indonesia

DKD $=$ Permintaan Kopi Indonesia

PKD $\quad=$ Harga Kopi Indonesia

DKW $=$ Permintaan Kopi Dunia

XKINA $=$ Ekspor Kopi Indonesia

$\mathrm{XKCOL}=$ Ekspor Kopi Kolombia

XKBRA $=$ Ekspor Kopi Brazil

MKUSA $=$ Impor Kopi Amerika Serikat

MKJEP = Impor Kopi Jepang

Variabel Eksogen :

HPPK = Rata - rata harga eceran tertinggi pupuk untuk kopi di Indonesia

PRDKVK $_{\mathrm{t}-1}=$ Produktivitas kopi di Indonesia pada tahun sebelumnya

$\mathrm{W}=$ Rata - rata upah tingkat pekerja perkebunan kopi di Indonesia

PPN = Pajak Pertambahan Nilai $10 \%$

PTD $=$ Harga Teh Indonesia

LAPK $_{\mathrm{t}-1}=$ Luas Areal Kopi di Indonesia pada Tahun Sebelumnya

POP = Populasi Penduduk Indonesia

PKW = Harga Kopi Dunia

ER = Nilai Tukar Rupiah terhadap Dollar

$\mathrm{PKD}_{\mathrm{t}-1}=$ Harga kopi di Indonesia pada Tahun Sebelumnya

ERCOL $=$ Nilai Tukar Peso terhadap Dollar

PRODKCOL $=$ Produksi Kopi Kolombia

$\mathrm{XKCOL}_{\mathrm{t}-1}=$ Ekspor Kopi Kolombia Tahun Sebelumnya

ERBRA =Nilai Tukar Real terhadap Dollar

PRODKBRA $=$ Produksi Kopi Brazil

$\mathrm{XKBRA}_{\mathrm{t}-1}=$ Ekspor Kopi Brazil Tahun Sebelumnya

KKUSA =Konsumsi Kopi Amerika Serikat

MKUSA $_{\mathrm{t}-1}=$ Impor Kopi Amerika Serikat Tahun Sebelumnya

ERJEP =Nilai Tukar Yen terhadap Dollar

http://www.habitat.ub.ac.id, ISSN: 0853-5167 (p); 2338-2007 (e) 


$$
\begin{aligned}
\text { KKJEP } & \text { Konsumsi Kopi Jepang } \\
\text { MKJEP }_{\mathrm{t}-1} & =\text { Impor Kopi Jepang Tahun } \\
& \text { Sebelumnya }
\end{aligned}
$$

\section{1) Identifikasi Model}

Gujarati (1999) menyatakan bahwa untuk menganalisis model simultan maka harus dilakukan identifikasi terlebih dahulu untuk menganalisis apakah model tersebut dapat disesuaikan dengan kondisi yang terjadi sebenarnya. Selain itu, identifikasi model simultan ini dipergunakan untuk memberikan justifikasi apakah setiap variabel dari model dapat merepresentasikan variabel utama analisis dalam sebuah penelitian, dalam hal ini model ekonomi kopi.

Tabel 1. Hasil Identifikasi Model Ekonomi Kopi di Indonesia

\begin{tabular}{cccccccl}
\hline Persamaan & Jenis Persamaan & $\mathbf{K}$ & $\mathbf{k}$ & $\mathbf{m}$ & $\mathbf{K}-\mathbf{k}$ & $\mathbf{m}-\mathbf{1}$ & Hasil \\
\hline PRDKVK & Struktural & 22 & 6 & 12 & 16 & 11 & $=16>11$, maka over identified \\
LAPK & Struktural & 22 & 3 & 12 & 19 & 11 & $=19>11$, maka over identified \\
DKD & Struktural & 22 & 4 & 12 & 18 & 11 & $=18>11$, maka over identified \\
PKD & Struktural & 22 & 4 & 12 & 18 & 11 & $=18>11$, maka over identified \\
DKW & Struktural & 22 & 5 & 12 & 17 & 11 & $=17>11$, maka over identified \\
XKINA & Struktural & 22 & 8 & 12 & 14 & 11 & $=14>11$, maka over identified \\
XKCOL & Struktural & 22 & 5 & 12 & 17 & 11 & $=17>11$, maka over identified \\
XKBRA & Struktural & 22 & 5 & 12 & 17 & 11 & $=17>11$, maka over identified \\
MKUSA & Struktural & 22 & 4 & 12 & 18 & 11 & $=18>11$, maka over identified \\
MKJEP & Struktural & 22 & 4 & 12 & 18 & 11 & $=18>11$, maka over identified \\
\hline
\end{tabular}

Sesuai dengan ketentuan prosedur identifikasi model simultan yang diaplikasikan dalam model penelitian ini, maka didapatkan hasil pada Tabel 1 .

Dari hasil identifikasi model pada Tabel 1., dapat disimpulkan bahwa model ekonomi kopi di Indonesia dalam penelitian ini over identified atau model simultan dalam peneitian ini layak untuk dianalisis pada tahap selanjutnya seperti metode two-stage-least-square (2SLS) dan beberapa pengujian model yang dijelaskan pada sub bab berikut.

\section{2) Validasi Model}

Uji validitas model simultan yang biasa dipergunakan adalah kesalahan rataan kuadrat terkecil (Root Mean Square Percent Error, RMSPE) dan koefisien ketidaksamaan Theil (Theil Inequality Coeficient, U). Statistik RSMPE digunakan untuk mengukur seberapa jauh nilainilai aktualnya dalam ukuran relatif atau seberapa dekat nilai-nilai dugaan itu mengikuti perkembangan aktualnya (Pindyick and Rubenfeld, 1998).

Nilai statistik RMPSE adalah:

RMPSE $=\left[\frac{1}{T} \sum_{t=1}^{T} \frac{\left(Y_{t}^{g}-Y_{t}^{a}\right)}{\left(Y_{t}^{a}\right)^{2}}\right]^{0,5}$

U-Theil melihat kemampuan model untuk peramalan yang nilainya berkisar $0-1$. Nilai statistik untuk U-Theil adalah sebagai berikut:

$$
U=\frac{\sqrt{\left(\frac{1}{T}\right) \Sigma_{t=1}^{T}\left(Y_{S}-Y_{Q}\right)^{2}}}{\sqrt{\left(\frac{1}{T}\right) \sum_{t=1}^{T} Y_{S}^{2}}+\sqrt{\left(\frac{1}{T}\right) \Sigma_{t=1}^{T} Y_{Q}^{2}}}
$$

Sedangkan dekomposisi dari U-Theil yaitu proporsi bias (UM), proporsi varians (US) dan proporsi kovarians (UC).

Suatu penaksir model atau variabel dikatakan valid jika $\mathrm{UM} \leq 0,20$, Nilai statistik UM adalah sebagai berikut:

$U M=\frac{\left(\bar{Y}_{S}-Y_{a}\right)^{2}}{\left(\frac{1}{T}\right) \Sigma_{t=1}^{T}\left(Y_{S}-Y_{a}\right)^{2}}$.

US merupakan indikator kesalahan dari komponen regresi yang mengukur penyimpangan kemiringan regresi. Nilai statistic US adalah sebagai berikut:

$U S=\frac{\left(\sigma_{S}-\sigma_{a}\right)^{2}}{\left(\frac{1}{T}\right) \sum_{t=1}^{T}\left(Y_{S}-Y_{a}\right)^{2}}$

UC merupakan ukuran kesalahan nonsistematis atau unsystematic error dari penaksir suatu model atau variabel. Nilai statistic UC adalah sebagai berikut:

$U C=\frac{\left\lfloor 2(1-\rho) \sigma_{S} \sigma_{a}\right\rfloor}{\left(\frac{1}{T}\right) \Sigma \Sigma_{t=1}^{T}\left(Y_{S}-Y_{a}\right)^{2}}$

$U M+U S+U C=1$

Keterangan:

$T=$ Jumlah tahun penelitian

$Y_{s}=$ Nilai taksiran model atau variabel

$\frac{Y_{s}}{Y_{s}}=$ Nilai taksiran rata-rata model atau variabel

$Y_{a}=$ Nilai observasi model atau variabel 
$\overline{Y_{a}}=$ Nilai observasi rata-rata model atau variabel

$\sigma_{s}=$ Standart deviasi nilai taksiran model atau variabel

$\sigma_{\alpha}=$ Standart deviasi nilai observasi model atau variabel

$\rho=$ Koefisien korelasi antara nilai taksiran dengan nilai observasi atau variable

\section{3) Pengujian Model Regresi}

a) Koefisien Determinasi $\left(\mathrm{R}^{2}\right)$

Suatu model mempunyai kebaikan dan kelemahan jika diterapkan dalam masalah yang berbeda. Untuk mengukur kebaikan suatu model (goodnes of fit) digunakan koefisien determinasi $\left(\mathrm{R}^{2}\right)$. Koefisien determinasi dirumuskan sebagai berikut :

$R^{2}=1-\frac{\sum(\hat{Y}-\bar{Y})^{2}}{\sum\left(Y_{i}-\bar{Y}\right)^{2}}=1-\frac{\sum \theta_{i}^{2}}{\sum y_{i}^{2}}$

b) Uji Signifikansi Simultan ( Uji F )

Menurut Gujarati (1999), uji F digunakan untuk menguji signifikansi keseluruhan variabel regresi yang diobservasi terhadap variabel terikat. Berikut ini merupakan rumus yang digunakan untuk menganalisis uji $\mathrm{F}$ pada penelitian :

$$
F=\frac{R^{2} /(k-1)}{\left(1-R^{2}\right) /(n-k]} \text {. }
$$

Dimana,

$\mathrm{R}^{2} \quad=$ Koefisien determinasi

$\mathrm{k} \quad=$ banyaknya peubah bebas

$\mathrm{n} \quad=$ ukuran sampel

\section{4) Pengujian Pendugaan Parameter Model}

Uji secara parsial yang digunakan dari masing masing variabel dalam model adalah uji t. Uji statistik $t$ dilakukan untuk menunjukkan seberapa jauh pengaruh satu variabel penjelas secara individual dalam menerangkan variasi variabel dependen (Ghozali, 2006).

Hipotesis yang digunakan adalah sebagai berikut ini:

$\mathrm{H}_{0}$ : $\mathrm{b}=0$; tidak ada pengaruh yang nyata dari perubahan variabel eksogen secara individu terhadap variabel endogen.

$\mathrm{H}_{\mathrm{a}}: \mathrm{b} \neq 0$; ada pengaruh yang nyata dari perubahan variabel eksogen secara individu terhadap variabel endogen.

\section{berikut ini :}

Probabilitas dari hipotesis adalah sebagai

Jika $t_{\text {hitung }}>t_{\text {tabel}}$, tolak $H_{0}$ dan menerima $H_{a}$, artinya adalah terdapat pengaruh yang nyata antara variabel eksogen dengan variabel endogen.
Jika $t_{\text {hitung }}<t_{\text {tabel }}$, terima $H_{0}$ dan menolak $H_{a}$, artinya adalah tidak teerdapat pengaruh yang nyata antara variabel eksogen dengan variabel endogen.

\section{b. Simulasi Alternatif Kebijakan}

Simulasi dipergunakan untuk menganalisis kebijakan yang sesuai untuk menjalankan kegiatan perekonomian dalam lingkup makro ataupun mikro. Akan tetapi, secara teoritis dalam persamaan simultan, simulasi ini dipergunakan untuk mengetahui dampak perubahan variabel eksogen terhadap variabel endogen dari masing masing model. Simulasi kebijakan pada penelitian ini dipergunakan dengan menggunakan prosedur SIMLIN (Simulation non Linear).

Adapun sekenario simulasi alternatif kebijakan dalam penelitian ini dengan menggunakan penerapan pengurangan dan penambahan PPN 10\% untuk komoditi ekspor kopi.

Menurut Pasal 7 Undang - undang Pajak Pertambahan Nilai, Kopi dikenakan pajak ekspor $10 \%$, namun pajak dapat berubah minimal 5\% dan $10 \%$. Akan tetapi pajak pertambahan nilai kopi dapat menjadi 0\% jika kopi dicantumkan dalam kategori ekspor barang kena pajak berwujud, ekspor barang kena pajak tidak berwujud, dan ekspor jasa kena pajak. Sehingga untuk skenario perubahan pajak pertambahan nilai adalah, $0 \%, 5 \%$, dan $15 \%$.

\section{Hasil dan Pembahasan}

\subsection{Faktor - faktor yang Mempengaruhi Ekonomi Kopi di Indonesia}

Sebelum menguraikan mengenai faktor faktor yang berpengaruh pada ekonomi kopi maka dilakukan uji validasi. Validasi model dilakukan dengan melihat dengan Root Mean Square Percent Error (RMSPE) dan Theil's Inequality Coefficient (U-Theil). Hasil validasi model dipaparkan pada Tabel 2.

Berdasarkan Tabel 2. maka dapat diljelaskan bahwa nilai RMSPE yang cukup kecil menunjukkan bahwa hasil pendugaan nilai-nilai variabel endogen tidak menyimpang terlalu jauh dari nilai-nilai aktualnya. Hal ini ditunjukkan dari jumlah peubah endogen yang divalidasi saluruh peubah memiliki nilai RMSPE lebih kecil dari $50 \%$. Validasi model dengan U-Theil serta dekomposisinya menunjukkan bahwa model dalam penelitian ini adalah baik. 
Dari hasil validasi model pada Tabel 7. dapat disimpulkan bahwa model ekonomi kopi dalam penelitian ini cukup baik digunakan untuk simulasi penelitan data secara historis. Hal ini ditunjukkan oleh indikator kesalahan rataan kuadrat terkecil dari RMSPE dan U-Theil.

Nilai UM nol yang berarti proporsi bias antara nilai simulasi dengan nilai aktual adalah sangat kecil. Nilai US mendekati nol menunjukkan bahwa penyimpangan kemiringan regresi sangat kecil. Nilai UC mendekati satu menunjukkan bahwa komponen bias residual juga sangat kecil. Nilai $U$ secara umum mendekati nol menunjukkan bahwa model sudah cukup baik digunakan untuk simulasi.

Tabel 2. Hasil Validasi Model Ekonomi Kopi Indonesia

\begin{tabular}{lccccc}
\hline \multicolumn{1}{c}{ Variabel } & RMS \%Error & Bias (UM) & Var(US) & Covar(UC) & U \\
\hline PRDKVK & 0.0141501 & 0.000 & 0.03218 & 0.968 & 0.04205 \\
LAPK & 0.0001420 & 0.000 & 0.13795 & 0.862 & 0.015783 \\
DKD & 0.0000243 & 0.000 & 0.01082 & 0.989 & 0.035483 \\
PKD & 0.0040537 & 0.000 & 0.08592 & 0.914 & 0.092654 \\
DKW & 0.0000053 & 0.000 & 0.01261 & 0.987 & 0.025918 \\
XKINA & 0.0000151 & 0.000 & 0.02604 & 0.974 & 0.043311 \\
XKCOL & 0.0000121 & 0.000 & 0.16164 & 0.838 & 0.04426 \\
XKBRA & 0.0000069 & 0.000 & 0.02422 & 0.976 & 0.035638 \\
MKUSA & 0.0000048 & 0.000 & 0.04887 & 0.951 & 0.021579 \\
MKJEP & 0.0000087 & 0.000 & 0.03706 & 0.963 & 0,017981 \\
\hline
\end{tabular}

\section{a. Model Persamaan Produktivitas Kopi di Indonesia}

Model pertama dari kinerja ekonomi kopi adalah produktivitas kopi. Berdasarkan Tabel 3. didapatkan nilai koefisien determinasi sebesar 0.8846 yang menunjukkan bahwa keragaan produktivitas kopi sebesar 88,46\% mampu merepresentasikan model produktivitas kopi di Indonesia. Sedangkan sisanya sebesar $11,54 \%$ dijelaskan oleh faktor - faktor diluar model.

Sedangkan hasil pengaruh secara parsial dari variabel yang berpengaruh nyata dengan nilai T-tabel 2.086 adalah sebagai berikut:

1) Terdapat pengaruh yang nyata antara variabel harga kopi Indonesia terhadap produktivitas kopi. Nilai koefisien 0.013260 menandakan bahwa peningkatan $1 \%$ harga kopi akan mengurangi produktivitas sebesar 0.013260 . Harga kopi tidak lagi ditentukan oleh produsen, namun pasar dan pemerintah. Sehingga peningkatan harga akan mempengaruhi pada pengurangan produktivitas.

2) Terdapat pengaruh yang nyata antara variabel rata - rata upah tingkat pekerja perkebunan kopi di Indonesia terhadap produktivitas kopi. Nilai koefisien 0.003380 menandakan bahwa peningkatan $1 \%$ upah pekerja perkebunan kopi akan menambah produktivitas sebesar 0.003380 . Hal ini dikarenakan sebagian besar eksportir lebih memilih mengambil kopi dari perkebunan rakyat dimana buruh perkebunan kopi bekerja.

3) Terdapat pengaruh yang nyata antara variabel pajak pertambahan nilai $10 \%$ terhadap produktivitas kopi. Nilai koefisien 3.37E-10 menandakan bahwa peningkatan $1 \%$ pajak pertambahan nilai $10 \%$ akan mengurangi produktivitas sebesar 3.37E-10. Penambahan pajak pertambahan nilai $10 \%$ pada ekspor kopi yang diterapkan kepada seluruh eksportir kopi dapat meningkatkan biaya produksi petani sejalan dengan peningkatan biaya produksi eksportir sehingga menyebabkan penurunan produktivitas.

Tabel 3. Hasil Pendugaan Produktivitas Kopi di Indonesia

\begin{tabular}{ccccc}
\hline Variabel & Koefisien & $\begin{array}{c}\text { Std. } \\
\text { Error }\end{array}$ & $\begin{array}{c}\text { t- } \\
\text { Statistic }\end{array}$ & Prob \\
\hline Konstanta & 893.69 & 306.47 & 2.9161 & 0.011 \\
LAPK & -0.0003 & 0.0002 & -1.6804 & 0.115 \\
HPPK & -0.0483 & 0.1266 & -0.3811 & 0.709 \\
PRDKVK $_{\text {t-1 }}$ & 0.0209 & 0.1649 & 0.1265 & 0.901 \\
PKD & -0.0133 & 0.0028 & -4.8137 & 0.001 \\
W & 0.0034 & 0.0014 & 2.2948 & 0.038 \\
PPN & $-3.4 \mathrm{E}-10$ & $6.8 \mathrm{E}-11$ & 4.9781 & 0.002 \\
\hline \multicolumn{4}{c}{0.884611} \\
R-squared & \multicolumn{3}{c}{17.88804} \\
\hline
\end{tabular}




\section{b. Model Persamaan Luas areal panen kopi di Indonesia}

Model selanjutnya yang dijadikan analisis kinerja ekonomi kopi adalah luas areapanen kopi. Berdasarkan Tabel 4. didapatkan Nilai koefisien determinasi sebesar 0.5894 dan menunjukkan bahwa keragaan luas areal tanam kopi sebesar 58.94\% mampu menunjukkan model luas areal panen kopi di Indonesia. Sedangkan sisanya sebesar $41.06 \%$ dijelaskan oleh faktor faktor diluar model.

Tabel 4. Hasil pendugaan Luas areal panen kopi di Indonesia

\begin{tabular}{ccccc}
\hline Variabel Koefisien & $\begin{array}{c}\text { Std. } \\
\text { Error }\end{array}$ & $\begin{array}{c}\text { t- } \\
\text { Statistic }\end{array}$ & Prob. \\
\hline Konstanta & 492197.4 & 245018.4 & 2.00882 & 0.061 \\
PKD & -1.99172 & 2.56887 & -0.77533 & 0.449 \\
PTD & 0.17488 & 1.57441 & 0.11105 & 0.913 \\
LAPK $_{\text {t-1 }}$ & 0.62914 & 0.18872 & 3.33382 & 0.004 \\
\hline \multicolumn{4}{c}{0.589444} & \\
R-squared & \multicolumn{3}{c}{8.135743} & \\
\hline
\end{tabular}

Hasil pengaruh secara parsial dari variabel yang berpengaruh nyata dengan nilai $\mathrm{T}$-tabel sebesar 2.086, bahwa pengaruh yang nyata antara variabel luas areal kopi di Indonesia pada tahun sebelumnya terhadap luas areal panen kopi. Nilai koefisien 0.629139 menandakan bahwa peningkatan $1 \%$ luas areal kopi tahun sebelumnya akan menambah luas areal sebesar 0.629139 Ha. Variabel lag luas areal panen berpengaruh positif dan nyata terhadap luas areal panen. Luas areal panen sebelumnya dijadikan dasar patokan pemerintah untuk peningkatan produksi kopi dengan peningkatan luas areal panen kopi.

\section{c. Model Persamaan Permintaan Kopi Indonesia}

Permintaan kopi Indonesia di Indonesia dipengaruhi oleh harga kopi Indonesia, populasi penduduk Indonesia, pendapatan perkapita, dan harga teh Indonesia. Hasil dugaan parameter permintaan kopi dapat dilihat pada Tabel 5.

Berdasarkan Tabel 5. didapatkan nilai koefisien determinasi sebesar 0.9596 dan menunjukkan bahwa keragaan permintaan kopi sebesar $95.96 \%$ mampu merepresentasikan model yakni harga kopi Indonesia, populasi penduduk Indonesia, pendapatan perkapita, dan harga teh Indonesia. Sedangkan sisanya sebesar $4.04 \%$ dijelaskan oleh faktor faktor diluar model.
Tabel 5. Hasil pendugaan Permintaan kopi Indonesia

\begin{tabular}{ccccc}
\hline Variabel & Koefisien & $\begin{array}{c}\text { Std. } \\
\text { Error }\end{array}$ & $\begin{array}{c}\text { t- } \\
\text { Statistic }\end{array}$ & Prob. \\
\hline Konstanta & $-5 \mathrm{E}+08$ & $1.2 \mathrm{E}+08$ & -4.14807 & 0.0008 \\
PKD & 1716.83 & 967.55 & 1.77441 & 0.0950 \\
POP & 2.70931 & 0.562 & 4.82057 & 0.0002 \\
I & $-1.3 E-09$ & $3.2 \mathrm{E}-09$ & -0.39593 & 0.6974 \\
PTD & 1009.35 & 618.82 & 1.63109 & 0.1224 \\
\hline \multicolumn{4}{c}{ R-squared } & \multicolumn{3}{c}{0.959630} \\
F-statistic & \multicolumn{3}{c}{95.08429} \\
\hline
\end{tabular}

Hasil pengaruh secara parsial dari variabel yang berpengaruh nyata dengan T-tabel 2.086, bahwa pengaruh yang nyata antara variabel populasi penduduk Indonesia terhadap permintaan kopi Indonesia. Secara statistik, nilai koefisien 2.709312 menandakan bahwa peningkatan $1 \%$ populasi penduduk Indonesia akan menambah permintaan kopi sebesar $2.709312 \mathrm{Kg}$. Hal ini sesuai dengan teori bahwa permintaan kopi dipengaruhi oleh populasi penduduk.

\section{d. Model Persamaan Harga Kopi di Indonesia}

Indikator berikutnya yang menjadi penggerak roda kinerja ekonomi kopi di Indonesia adalah harga kopi. Berdasarkan Tabel 6. didapatkan Nilai koefisien determinasi sebesar 0.7203 yang dapat diartikan bahwa keragaan harga kopi di Indonesia sebesar 72.03\% mampu merepresentasikan model. Sedangkan sisanya sebesar $27.97 \%$ dijelaskan oleh faktor faktor diluar model.

Hasil pengaruh secara parsial dari variabel yang berpengaruh nyata dengan nilai $\mathrm{T}$-tabel 2.086 dapat dilihat sebagai berikut :

1) Terdapat pengaruh yang nyata antara variabel harga kopi dunia terhadap harga kopi di Indonesia. Nilai koefisien 0.509749 menandakan bahwa peningkatan $1 \%$ harga kopi dunia akan menambah harga kopi Indonesia sebesar Rp0.509749. Kondisi yang demikian disebabkan karena Indonesia merupakan salah satu negara pengekspor kopi terbesar di dunia. Sehingga harga kopi dunia mempengaruhi secara tidak langsung terhadap harga kopi di Indonesia.

2) Terdapat pengaruh yang nyata antara variabel Harga kopi Indonesia tahun sebelumnya terhadap harga kopi di Indonesia. Nilai koefisien 0.417060 menandakan bahwa peningkatan $1 \%$ harga 
kopi Indonesia tahun sebelumnya akan menambah harga kopi Indonesia sebesar Rp0.417060. Selain dari permintaan dan penawaran, regulasi penentuan standar harga kopi domestik ditentukan oleh harga kopi pada tahun sebelumnya, yang ditujukan untuk memberikan perubahan terhadap variabel lain yang dipengaruhi harga.

Tabel 6. Hasil pendugaan Harga Kopi di Indonesia

\begin{tabular}{ccccc}
\hline Variabel & Koefisien & $\begin{array}{c}\text { Std. } \\
\text { Error }\end{array}$ & $\begin{array}{c}\text { t- } \\
\text { Statistic }\end{array}$ & Prob. \\
\hline Koefisien & 13082.32 & 5363.4 & 2.4391 & 0.027 \\
PKW & 0.509749 & 0.197 & 2.5870 & 0.019 \\
ER & -1.469399 & 0.5089 & -2.8872 & 0.011 \\
PKD $_{\text {t-1 }}$ & 0.417060 & 0.198 & 2.0961 & 0.052 \\
SKINA & $1.27 E-05$ & $1.7 \mathrm{E}-05$ & 0.7755 & 0.449 \\
\hline R-squared & \multicolumn{3}{c}{0.720330} \\
F-statistic & \multicolumn{3}{c}{10.30259} \\
\hline
\end{tabular}

\section{e. Model Permintaan Kopi Dunia}

Model permintaan kopi dunia menjadi penting bagi kinerja ekonomi kopi di Indonesia karena kopi merupakan komoditi ekspor yang menjadi unggulan dari Indonesia.

Tabel 7. Hasil pendugaan Permintaan Kopi Dunia

\begin{tabular}{ccccc}
\hline Variabel & Koefisien & $\begin{array}{c}\text { Std. } \\
\text { Error }\end{array}$ & t-Statistic & Prob. \\
\hline Konstanta & $9.2 \mathrm{E}+08$ & $2.65 \mathrm{E}+08$ & 3.484017 & 0.0031 \\
PKW & 24530.6 & 5132.044 & 4.779883 & 0.0002 \\
XKINA & 0.29182 & 0.321162 & 0.908653 & 0.3770 \\
XKBRA & 0.76112 & 0.096239 & 7.908619 & 0.0000 \\
XKCOL & 1.01542 & 0.346946 & -2.926743 & 0.0099 \\
\hline R-squared & \multicolumn{3}{c}{0.953101} & \\
F-statistic & \multicolumn{3}{c}{81.28973} \\
\hline
\end{tabular}

Berdasarkan Tabel 7. didapatkan nilai koefisien determinasi menunjukkan sebesar 0.9531 dan diartikan bahwa keragaan permintaan kopi sebesar $95.31 \%$ mampu merepresentasikan model permintaan kopi dunia. Sedangkan sisanya sebesar $4.69 \%$ dijelaskan oleh faktor faktor diluar model.

Hasil pengaruh dari variabel yang berpengaruh nyata secara parsial dengan nilai Ttabel 2.086 dapat dilihat sebagai berikut :

1) Terdapat pengaruh yang nyata antara variabel harga kopi dunia terhadap permintaan kopi dunia. Nilai koefisien 24530.57 menandakan bahwa peningkatan $1 \%$ harga kopi dunia akan menambah permintaan kopi dunia sebesar 24530.57 $\mathrm{Kg}$. Kondisi berpengaruhnya permintaan terhadap harga sesuai dengan kondisi hukum permintaan, namun hal ini berbeda dengan hubungan positif yang dimiliki permintaan dan harga kopi dunia. Hal ini dikarenakan beberapa varian kopi masuk kepada jenis barang superior.

2) Terdapat pengaruh yang nyata antara variabel ekspor kopi Brasil terhadap permintaan kopi dunia. Nilai koefisien 0.761121 menandakan bahwa peningkatan $1 \%$ ekspor kopi Brasil akan menambah permintaan kopi dunia sebesar 0.761121 $\mathrm{Kg}$. Hal ini dikarenakan tingkat ekspor kopi Brasil yang sangat tinggi, sehingga banyaknya kopi yang dikonsumsi dunia sebagian besar akan bergantung pada ekspor kopi Brasil.

3) Terdapat pengaruh yang nyata antara variabel ekspor kopi Kolombia terhadap permintaan kopi dunia. Nilai koefisien 1.015422 menandakan bahwa peningkatan $1 \%$ ekspor kopi Kolombia akan menambah permintaan kopi dunia sebesar 1.015422 Kg. Ekspor kopi kolombia sama dengan ekspor kopi Brasil, sebagian besar kopi kolombia berhasil menarik minat konsumen kopi dunia.

\section{f. Model Persamaan Ekspor Kopi Indonesia}

Indikator kinerja ekonomi kopi di Indonesia yang berperan penting salah satunya adalah ekspor kopi. Berdasarkan Tabel 8. didapatkan Nilai koefisien determinasi sebesar 0.9055 dan dapat diartikan bahwa Ekspor Kopi Indonesia sebesar $90.55 \%$ mampu merepresentasikan model ekspor kopi Indonesia. Sedangkan sisanya sebesar $9.45 \%$ dijelaskan oleh faktor faktor diluar model.

Tabel 8. Hasil pendugaan Ekspor Kopi Indonesia

\begin{tabular}{ccccc}
\hline Variable & Koefisien & $\begin{array}{c}\text { Std. } \\
\text { Error }\end{array}$ & $\begin{array}{c}\text { t- } \\
\text { Statistic }\end{array}$ & Prob. \\
\hline Konstanta & $-1.1 \mathrm{E}+08$ & $1.2 \mathrm{E}+08$ & -0.84001 & 0.416 \\
PKW & -5978.59 & 3086.01 & -1.93733 & 0.075 \\
ER & 13950.1 & 6904.78 & 2.02035 & 0.064 \\
PRODK & 0.56942 & 0.17346 & 3.28275 & 0.006 \\
DKW & 0.03813 & 0.0888 & 0.42888 & 0.675 \\
XKBRA & -0.08549 & 0.08444 & -1.01241 & 0.32 \\
XKCOL & 0.15136 & 0.14879 & 1.01727 & 0.328 \\
PPN & -0.00021 & $7.0 \mathrm{E}-05$ & 2.95199 & 0.011 \\
\hline \multicolumn{5}{r}{ R-squared } \\
F-statistic & \multicolumn{3}{c}{0.905532} \\
\hline
\end{tabular}

http://www.habitat.ub.ac.id, ISSN: 0853-5167 (p); 2338-2007 (e) 
Hasil pengaruh secara parsial dari variabel yang berpengaruh nyata dengan T-tabel 2.086 dapat dilihat sebagai berikut :

1) Terdapat pengaruh yang nyata antara variabel total produksi kopi Indonesia terhadap Ekspor Kopi Indonesia. Nilai koefisien 0.569419 menandakan bahwa peningkatan $1 \%$ produksi kopi menambah Ekspor Kopi Indonesia sebesar 0.569419 $\mathrm{Kg}$. Secara garis besar, kopi di Indonesia ditujukan untuk diekspor ke negara negara impotir. Hal ini dibuktikan dengan lebih besarnya jumlah ekspor dibandingkan dengan konsumsi dalam negeri.

2) Terdapat pengaruh yang nyata antara variabel pajak pertambahan nilai $10 \%$ terhadap Ekspor Kopi Indonesia. Nilai koefisien -0.000207 menandakan bahwa peningkatan $1 \%$ pajak pertambahan nilai akan mengurangi Ekspor Kopi Indonesia sebesar $0.000207 \mathrm{Kg}$. Pemberlakuan pajak pertambahan nilai akan menambah biaya produksi petani, sehingga petani mengalami penurunan keuntungan. Dengan kondisi yang demikian, produksi akan mengalami penurunan karena motivasi petani untuk menanam kopi rendah. Sehingga produksi akan mengalami penurunan.

\section{g. Model Persamaan Ekspor Kopi Kolombia}

Salah satu negara pesaing dari ekspor kopi di Indonesia adalah Kolombia. Berdasarkan Tabel 9. didapatkan Nilai koefisien determinasi sebesar 0.5375 yang dapat diartikan bahwa keragaan Ekspor Kopi Kolombia sebesar 53.75\% mampu merepresntasikan model ekspor kopi Kolombia. Sedangkan sisanya sebesar $46.25 \%$ dijelaskan oleh faktor faktor diluar model.

Tabel 9. Hasil pendugaan Ekspor Kopi Kolombia

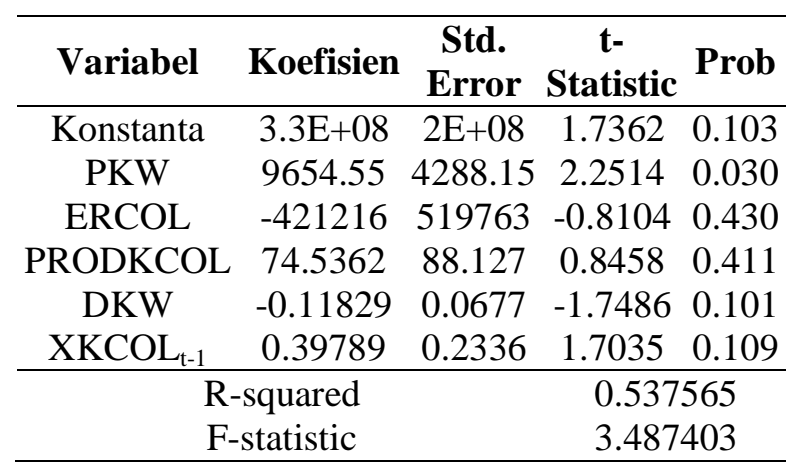

Sedangkan hasil pengaruh secara parsial dari faktor yang berpengaruh nyata dengan nilai T-tabel 2.086, bahwa nilai T-statistics (T-hitung) pada variabel harga kopi dunia sebesar 2.251448 menunjukkan bahwa terdapat pengaruh yang nyata antara variabel harga kopi dunia terhadap Ekspor Kopi Kolombia. Nilai koefisien 9654.553 menunjukkan bahwa peningkatan $1 \%$ harga kopi dunia menambah Ekspor Kopi Kolombia sebesar 9654.553 Kg. Hal ini disebabkan karena Ekspor kopi Kolombia memberikan pengaruh yang sangat besar terhadap permintaan kopi dunia.

\section{h. Model Persamaan Ekspor Kopi Brasil}

Selain kolombia, negara eksportir kopi lainnya yang masih berada jauh tingkat ekspornya dari Indonesia adalah Brasil.

Tabel 10. Hasil pendugaan Ekspor Kopi Brasil

\begin{tabular}{ccccc}
\hline Variabel & \multirow{2}{*}{ Koefisien } & $\begin{array}{c}\text { Std. } \\
\text { Error }\end{array}$ & $\begin{array}{c}\text { t- } \\
\text { Statistic }\end{array}$ & Prob. \\
\hline Konstanta & 12393432 & $1.6 \mathrm{E}+08$ & 0.07881 & 0.938 \\
PKW & -8519.669 & 7640.64 & -1.11505 & 0.282 \\
ERBRA & 36936.27 & 15196.9 & 2.43051 & 0.028 \\
PRODKBRA & -0.068711 & 0.08971 & -0.76590 & 0.456 \\
DKW & 0.605591 & 0.22475 & 2.69449 & 0.017 \\
XKBRA $_{t-1}$ & 0.209268 & 0.23808 & 0.87899 & 0.393 \\
\hline \multicolumn{4}{c}{ R-squared } & \multicolumn{3}{c}{0.911838} \\
F-statistic & & 31.02836 \\
\hline
\end{tabular}

Berdasarkan Tabel 10. didapatkan Nilai koefisien determinasi sebesar 0.9118 yang dapat diartikan bahwa keragaan Ekspor Kopi Brasil sebesar $91.18 \%$ mampu merepresentasikan model ekspor kopi brasil. Sedangkan sisanya sebesar $8.72 \%$ dijelaskan oleh faktor - faktor diluar model.

Sedangkan hasil pengaruh secara parsial dengan nilai T-tabel 2.086 dapat dilihat sebagai berikut :

1) Terdapat pengaruh yang nyata antara variabel nilai tukar real Brasil terhadap dollar terhadap Ekspor Kopi Brasil. Nilai koefisien 36936.27 menandakan bahwa peningkatan $1 \%$ nilai tukar Real menambah Ekspor Kopi Brasil sebesar 36936.27 Kg. Hal ini disebabkan karena real Brasil tidak begitu tinggi nilai tukarnya terhadap dollar dibandingkan dengan Indonesia dan Kolombia.

2) Terdapat pengaruh yang nyata antara variabel permintaan kopi duniaterhadap Ekspor Kopi Brasil. Nilai koefisien 0.605591 menandakan bahwa peningkatan $1 \%$ permintaan kopi dunia menambah 
Ekspor Kopi Brasil sebesar 0.605591 Kg. Hal ini dikarenakan kopi Brasil merupakan negara dengan nilai dan volume ekspor kopi yang terbesar di dunia.

\section{i. Model Persamaan Impor Kopi Amerika serikat}

Impor Kopi Amerika serikat dipengaruhi oleh harga kopi dunia, konsumsi kopi Amerika serikat, dan impor kopi Amerika serikat tahun sebelumnya. Hasil dugaan parameter permintaan kopi dapat dilihat pada Tabel 11.

Tabel 11. Hasil pendugaan Impor Kopi Amerika Serikat

\begin{tabular}{ccccc}
\hline Variablel & Koefisien & $\begin{array}{c}\text { Std. } \\
\text { Error }\end{array}$ & $\begin{array}{c}\text { t- } \\
\text { Statistic }\end{array}$ & Prob. \\
\hline Konstanta & $2 \mathrm{E}+08$ & $2 \mathrm{E}+08$ & 0.8326 & 0.417 \\
PKW & 1577.7 & 2974.3 & 0.5305 & 0.603 \\
KKUSA & 0.4709 & 0.3661 & 1.2864 & 0.216 \\
MKUSA $_{\mathrm{t}-1}$ & 0.4318 & 0.2201 & 1.9616 & 0.066 \\
\hline \multicolumn{4}{c}{0.830026} \\
R-squared & \multicolumn{3}{c}{0.000001} \\
\hline
\end{tabular}

Berdasarkan Tabel 11. didapatkan Nilai koefisien determinasi ebesar 0.8300 yang dapat diartikan bahwa keragaan Impor KopiAmerika serikat sebesar $83.00 \% \quad$ mampu merepresentasikan model yakni harga kopi dunia, konsumsi kopi Amerika serikat, dan impor kopi Amerika serikat tahun sebelumnya. Sedangkan sisanya sebesar $17.00 \%$ dijelaskan oleh faktor faktor diluar model.

Nilai F-statistics sebesar 27.67177 menunjukkan bahwa terdapat pengaruh secara bersamaan variabel yang mempengaruhi impor kopi Amerika terhadap Impor Kopi Amerika serikat. Sedangkan hasil pengaruh secara parsial dari variabel yang berpengaruh nyata dengan nilai T-tabel 2.086 tidak ada.

\section{j. Model Persamaan Impor Kopi Jepang}

Berdasarkan Tabel 12. didapatkan Nilai koefisien determinasi sebesar 0.8683 yang dapat diartikan bahwa keragaan Impor Kopi Jepang sebesar $86.83 \%$ mampu merepresentasikan model impor kopi Jepang. Sedangkan sisanya sebesar $13.17 \%$ dijelaskan oleh faktor faktor diluar model.

Nilai F-statistics sebesar 26.36685 menunjukkan bahwa terdapat pengaruh secara bersamaan variabel yang mempengaruhi impor kopi Jepang tahun sebelumnya terhadap Impor Kopi Jepang.

Sedangkan hasil pengaruh secara parsial dengan nilai T-tabel 2.086, bahwa terdapat pengaruh yang nyata antara variabel Konsumsi kopi Jepang terhadap Impor Kopi Jepang. Nilai koefisien 1.446177 menandakan bahwa peningkatan $1 \%$ konsumsi kopi Jepang menambah Impor Kopi Jepang sebesar 1.446177 Kg. Kondisi ini disebabkan karena regulasi pemerintah Jepang untuk meningkatkan konsumsi dalam negeri.

Tabel 12. Hasil pendugaan Impor Kopi Jepang

\begin{tabular}{ccccc}
\hline Variabel & \multicolumn{2}{c}{ Koefisien Std. Error } & $\begin{array}{c}\text { t- } \\
\text { Statistic }\end{array}$ & Prob. \\
\hline Konstanta & -55614185 & 71667212 & -0.776 & 0.4491 \\
PKW & 79.39735 & 603.1116 & 0.132 & 0.8969 \\
ERJEP & 1955.881 & 2365.885 & 0.827 & 0.4206 \\
KKJEP & 1.446177 & 0.333514 & 4.336 & 0.0005 \\
MKJEP & -0.330650 & 0.219925 & -1.504 & 0.1522 \\
\hline \multicolumn{4}{c}{ R-squared } & 0.868277 \\
F-statistic & \multicolumn{3}{c}{26.36685} \\
\hline
\end{tabular}

3.2. Dampak Kebijakan Pajak Pertambahan Nilai Terhadap Kinerja Ekonomi Kopi di Indonesia

Berdasarkan model dari penelitian dan hasil analisis pada sub-bab sebelumnya, didapatkan hasil bahwa dari variabel produktivitas kopi dan ekspor kopi di Indonesia, pajak pertambahan nilai berpengaruh secara nyata dan berpengaruh secara negatif atau dapat mengurangi tingkat produktivitas dan ekspor secara berturut - turut sebesar sebesar 3,37 $\times 10^{-10}$ $\mathrm{Kg} / \mathrm{Ha}$ dan $0.000207 \mathrm{Kg}$.

Jika penurunanan produktivitas terjadi maka secara langsung produksi kopi di Indonesia akan mengalami penurunan sebesar $3,37 \times 10^{-10}$ tiap perubahan luas areal panen. Penurunan produksi kopi ini akan berakibat pada dua sektor pasar perkopian, yaitu sektor internasional dan domestik:

a. Pada sektor pasar kopi domestik, penurunan produksi akan menyebabkan penawaran kopi di Indonesia akan mengalami penurunan sebesar $3,37 \times 10^{-10}$ per perubahan luas areal panen dikurangi perubahan ekspor.

b. Pada sektor pasar kopi internasional penurunan produksi akan mengurangi ekspor kopi Indonesia sebesar 0.569419 $\mathrm{Kg}$, dan juga sebaliknya. 
Tabel 13. Hasil Simulasi Kebijakan Perubahan Pajak Pertambahan Nilai 0\%

\begin{tabular}{ccccc}
\hline & \multicolumn{3}{c}{ PPN 0\% } \\
\hline \multirow{2}{*}{ Variabel } & \multirow{2}{*}{ Nilai Awal } & \multirow{2}{*}{ Nilai Simulasi } & \multicolumn{2}{c}{ Perubahan } \\
\cline { 4 - 5 } & & 456,9 & 64,9 & Persentase \\
\hline PRDKVK & 392 & 1.245 .852 & 0 & $16,56 \%$ \\
LAPK & 1.245 .852 & 149.662 .245 & 85.102 & $0 \%$ \\
DKD & 149.577 .143 & 13.541 & -1544 & $0,059 \%$ \\
PKD & 15.085 & 1.995 .256 .354 & 6.067 .160 & $-10,24 \%$ \\
DKW & 1.989 .189 .194 & 389.256 .823 & 27.075 .115 & $0,31 \%$ \\
XKINA & 362.181 .708 & & & $7,48 \%$ \\
\hline
\end{tabular}

\subsection{Alternatif Kebijakan Guna Memperbaiki Kinerja Perekonomian Kopi di Indonesia}

Terdapat beberapa alternatif perubahan kebiijakan skenario dalam simulasi model perekonomian kopi di Indonesia diantaranya adalah $0 \%, 5 \%$, dan $15 \%$, dengan nilai awal PPN yang disimulasikan adalah $10 \%$.

Pada pengurangan pajak hingga $0 \%$ yang ditunjukkan Tabel 13., rata -rata produktivitas kopi bertambah sekitar $16,56 \%$ dari nilai awal, dengan tingkat jumlah luas areal panen kopi yang tetap. Hal ini disebabkan karena pajak pertambahan nilai yang dihilangkan berdampak pada pengurangan biaya input petani kopi yang mayoritas merupakan petani di daerah dengan lahan milik pribadi, sehingga harga kopi yang dibeli eksportir menjadi menurun.

Perubahan ini juga berdampak pada rata rata permintaan kopi domestik yang bertambah sekitar 0,059\%, harga kopi di Indonesia yang juga berkurang sekitar $-10,24 \%$, rata - rata permintaan kopi dunia yang bertambah sekitar $0,31 \%$, serta pertambahan ekspor kopi Indonesia sekitar 7,48.

Tabel 14. Hasil Simulasi Kebijakan Perubahan Pajak Pertambahan Nilai 5\%

\begin{tabular}{|c|c|c|c|c|}
\hline \multirow{3}{*}{ Variabel } & \multicolumn{2}{|r|}{ PPN 5\% } & & \\
\hline & & & \multicolumn{2}{|c|}{ Perubahan } \\
\hline & Nilal Awal & Nilai Simulasi & Nilai & Persentase \\
\hline PRDKVK & 392 & 426,1 & 34,1 & $8,69 \%$ \\
\hline LAPK & 1.245 .852 & 1.245 .852 & 0 & $0 \%$ \\
\hline DKD & 149.577 .143 & 149.602 .365 & 25.222 & $0,017 \%$ \\
\hline PKD & 15.085 & 14.251 & -834 & $-5,53 \%$ \\
\hline DKW & 1.989.189.194 & 1.990 .547 .248 & 1.358 .054 & $0,07 \%$ \\
\hline XKINA & 362.181 .708 & 373.105 .785 & 10.924 .077 & $3,02 \%$ \\
\hline
\end{tabular}

Pada pengurangan tingkat presentase pajak pertambahan nilai menjadi 5\% seperti pada Tabel 14., kondisi yang sama juga berlaku untuk seluruh variabel yang memiliki pengaruh pada model perekonomian kopi Indonesia, akan tetapi memilki dampak yang lebih kecil daripada penghilangan pajak pertambahan nilai dari komoditi kopi. Perubahan yang terjadi pada variabel produktivitas adalah penambahan sekitar $8,69 \%$, dengan luas areal panen yang tidak berubah. Kemudian pada variabel permintaan kopi domestik bertambah sekitar $0,017 \%$, harga kopi domestik yang berkurang sekitar $-5,53 \%$, permintaan kopi dunia yang bertambah sekitar
$0,07 \%$, serta ekspor kopi Indonesia yang bertambah sekitar 3,02\%.

Sedangkan pada penambahan nilai pajak pertambahan nilai menjadi $15 \%$ yang telah disajikan pada Tabel 15. berdampak negatif pada seluruh variabel yang berpengaruh pada model perekonomian kopi di Indonesia. Hal ini sangat memungkinkan terjadi dikarenakan, penambahan pajak berarti menambah biaya input produksi dari petani sehingga eksportir mematok harga yang lebih tinggi dari harga kopi pada umumnya. Kondisi ini juga berdampak pada pengurangan luas lahan dikarenakan banyaknya petani yang berpindah menanam komoditi lainnya. 
Tabel 15. Hasil Simulasi Kebijakan Perubahan Pajak Pertambahan Nilai 15\%.

\begin{tabular}{|c|c|c|c|c|}
\hline \multicolumn{5}{|c|}{ PPN 15\% } \\
\hline \multirow{2}{*}{ Variabel } & \multirow{2}{*}{ Nilai Awal } & \multirow{2}{*}{ Nilai Simulasi } & \multicolumn{2}{|c|}{ Perubahan } \\
\hline & & & Nilai & Persentase \\
\hline PRDKVK & 392 & 321,6 & $-70,4$ & $-17,96 \%$ \\
\hline LAPK & 1.245 .852 & 1.231 .789 & -14.063 & $-1,13 \%$ \\
\hline DKD & 149.577.143 & 145.689 .554 & -3.887 .589 & $-2,6 \%$ \\
\hline PKD & 15.085 & 16.569 & -1.474 & $-9,77 \%$ \\
\hline DKW & 1.989.189.194 & 1.989 .189 .194 & 0 & $0 \%$ \\
\hline XKINA & 362.181 .708 & 312.589 .669 & -49.592 .039 & $-13,69 \%$ \\
\hline
\end{tabular}

Perubahan yang paling besar terjadi pada produktivitas, yaitu sekitar $-17,96 \%$, kemudian pada variabel luas areal panen juga berkurang sekitar $-1,13 \%$, permintaan kopi domestik juga berkurang sekitar $-2,6 \%$, harga kopi yang berlaku di Indonesia juga bertambah sekitar $-9,77 \%$, permintaan kopi dunia tidak terpengaruh, sehingga tidak mengalami perubahan sama sekali, serta ekspor kopi Indonesia juga berkurang seiring berkurangnya produktivitas kopi, yaitu sekitar $-13,69 \%$.

\section{Kesimpulan}

Faktor yang paling berperan penting dalam model perkonomian kopi di Indonesia adalah permintaan kopi di Indonesia. Permintaan kopi di Indonesia perlu ditingkatkan, salah satu caranya adalah dengan melihat potensi pasar, jenis kopi yang seperti apa dan bagaimana yang paling diminati oleh konsumen kopi di Indonesia.

Selain itu, Berdasarkan hasil penelitian dampak secara langsung penerapan pajak pertambahan nilai akan mengurangi nilai ekspor dan produktivitas dari kopi di Indonesia. Jika produktivitas kopi menurun, maka produksi kopi akan mengalami penurunan dengan luas areal panen yang tetap. Pada pasar kopi domestik, penurunan produksi akan mengakibatkan penurunan penawaran. Pada pasar kopi internasional, produksi akan mengakibatkan penurunan ekspor kopi Indonesia.

Sehingga alternatif skenario kebijakan yang paling sesuai dalam meningkatkan kinerja ekonomi kopi di Indonesia adalah dengan menghilangkan atau menunurunkan hingga 0\% pemberlakuan pajak pertambahan nilai pada eksportir kopi di Indonesia.

\section{Daftar Pustaka}

Anindita, Ratya dan Michael R. Reed. 2008. Bisnis dan Perdagangan Internasional. Andi. Yogyakarta.
Anindita, Ratya. 2008. Pendekatan Ekonomi Untuk Analisis Harga. Prenada Media Group. Jakarta.

Asosiasi Eksportir Kopi Jawa Timur. 2015. Ekspor Kopi. Available at http://aekijatim.co.nr. Diakses pada tanggal 25 November 2015.

Asosiasi Eksportir Kopi Indonesia. 2013. Ekspor Kopi. Available at http://aeki-aice.org. Diakses pada tanggal 18 November 2015.

Badan Pusat Statistik. 2015. Berita Resmi Statistik 2015. Badan Pusat Statistik. Jakarta.

Eriyanto, Pipit. 2015. Pemberlakuan PPN Ekspor Kopi. Available at http://disperindag.jatimprov.go.id.

Diakses pada tanggal 7 Desember 2015.

Ghozali, Imam. 2006. Aplikasi Analisis Multivariate Dengan Program SPSS. Badan Penerbit Undip. Semarang.

Gujarati, Damodar. 1999. Econometrics: Second Edition. McGraw Hill Book Co. Singapore.

Hakim, Abdul dan Yuli Hariyati. 2008. Dampak Liberalisasi Perdagangan Dunia terhadap Permintaan dan Penawaran Kopi Indonesia. Universitas Jember. Jember.

International Coffe Organization. 2014. World Coffe Consumption. International Coffee Organization. London.

Kementrian Perindustrian Dalam Negeri. 2015. Peningkatan Ekspor Kopi. Available at http://kemenperin.go.ig. Diakses pada tanggal 1 Desember 2015.

Pindyck, R.S. and D.L Rubinfeld. 1998. Econometric Models and Economic Forecast, Fourth Edition. McGraw-Hill International Edition. Singapore. 
Zuhdi, Fadhlan. 2014. Faktor - faktor yang Berpengaruh terhadap Pangsa Ekspor Kopi Indonesia di Pasar Internasional. Universitas Brawijaya. Malang. 